\title{
Is Supply Chain Management Replacing Operations Management in the Business Core Curriculum?
}

\author{
Gurkan I. Akalin \\ School of Business, Eastern Illinois University, USA \\ E-mail: giakalin@eiu.edu (Corresponding Author). \\ Zhentu Huang \\ School of Business, Eastern Illinois University, USA \\ E-mail: zhuang@eiu.edu. \\ John R. Willems \\ School of Business, Eastern Illinois University, USA \\ E-mail: jrwillems@eiu.edu
}

\begin{abstract}
This study reviews the core requirements in 447 business departments accredited by the Association to Advance Collegiate Schools of Business (AACSB) in order to understand the current status and changes of Operations Management and Supply Chain Management offerings in the business core. The field of SCM continues to grow in the 21 st century in terms of both industry demand and academic offerings. After the 2000s, many institutes of higher education realized the importance of SCM and the demand for trained individuals in the area. SCM became a common elective course for many business schools. This study is interested in exploring the next stage of implementing SCM into business education curriculum. This study seeks to determine if SCM is becoming a core business class for the majority of the business schools, or, more dramatically, if SCM is on the path of replacing OM. We report our survey results in order to understand the motivation for the changes related to SCM in the business core curriculum, the student and faculty reaction to these changes, and its effect on student enrollment, internships and employment.
\end{abstract}

Keywords: supply chain management, operations management, undergraduate core curriculum, business education, the association to advance collegiate schools of business.

\section{INTRODUCTION}

Today, a large organization without a proper supply chain management (SCM) strategy cannot be envisaged. During the last 20 years, "SCM" has broadened the scope of logistics and is recently being recognized as a core business competency (Alfalla-Luque \& Medina-Lopez, 2009; Korn, 2013). In response to the increasing interest and popularity, universities continue to offer more classes in SCM than ever before (Ellram \& Cooper, 2014). How to best incorporate SCM into the current undergraduate business curriculum remains a question. Institutes of higher education need to carefully consider the costs and benefits of integrating supply chain into the business core. In this study, we look at schools who have already implement changes in their business core to accommodate more SC content, and we identify their experience during the implementation process and afterwards.

Many universities and colleges offer SCM related courses as electives for interested students. Additionally, some of these universities have started offering a fully designated undergraduate program in SCM similar to the well-established degrees in marketing, finance, operations management, and accounting. By having electives in SCM and specialized SCM degrees, business schools expect to provide new opportunities for their students to work in SCM and related areas while remaining competitive in the global education market. A third option is to make SCM a required course as a part of the business core curriculum. Having SCM as part of the business core would allow all students to have exposure to the field including those who do not plan a career in the SCM field. Adding a subject to already overly crowded business core curriculum may require dropping a "similar" subject from the core or combining SCM with a "similar" subject under single course. As the closest related subject in the business core, Operations Management is potentially the course most likely to be affected by the recent success of SCM. It is already a routine to find modern operations management courses with much more supply chain content (Chase \& Zhang, 1998).

In this study, we conduct a survey of the universities/colleges that have made significant changes to 
include SCM in their business core. In this paper, we attempt to answer the following questions.

- What percentage of US business schools offer OM, $\mathrm{SCM}$ or a combined OM \& SCM related course in their curriculum?

- What is the main motivation to include SCM in the business core?

- Are their interesting similarities in the demographic data of the schools leading the charge of including additional SCM content in their business curriculum?

- What is the impact on student enrollment after this implementation?

- What was the reaction of stakeholders including students, business faculty and OM faculty towards the SCM related changes in the core curriculum?

- What were the costs of implementing these changes and where did the funding for these changes come from?

- How has the change to include more SCM in the business core affected student internships and employment?

This study is important because it is the first study to investigate the current state of SCM integration in the business core curriculum at AACSB accredited business schools and because there is an increasing need to understand the best ways to include SCM content in business schools. Our study will help business schools by bringing the real data that summarizes the general trend on how additional SCM content has been implement into the business curriculum. One of the common reasons for new curriculum development is to synchronize with changes at the programs in other institutes (Grandzol \& Grandzol, 2011). This study aims at bringing the aggregation in recent business core development in terms of SCM.

\section{LITERATURE REVIEW}

SCM is an interdisciplinary, process-based, and boundary-spanning activity (Bowersox, Closs, Cooper, \& Bowersox, 2013; Jones, Cope, \& Budden, 2009). In fact, a broad definition of SCM can include topics in traditional areas of business including marketing, finance, information systems, operations management, and accounting (Jones, Cope, \& Budden, 2009). As a result, the curriculum development for SCM can be as diverse as the subject content itself (Neureuther \& O’Neill, 2011). The Council of Supply Chain Management Professionals (CSCMP) (2013) defines SCM as follows.

Supply Chain Management encompasses the planning and management of all activities involved in sourcing and procurement, conversion, and all logistics management activities. Importantly, it also includes coordination and collaboration with channel partners, which can be suppliers, intermediaries, third-party service providers, and customers. In essence, supply chain management integrates supply and demand management within and across companies. ...

It includes all of the logistics management activities noted above, as well as manufacturing operations, and it drives coordination of processes and activities with and across marketing, sales, product design, finance, and information technology.

The definition of SCM provided by CSCMP is a very broad definition that not only includes core OM subjects such as manufacturing operations, but it is also an interdisciplinary subject requiring SCM professionals to understand and communicate well with other areas of the business, including marketing, sales, finance, information technology, etc. Thus, including SCM into the core curriculum can not only prepare students in one of the newest area of business, but also enable them to develop the interdisciplinary skills that contemporary business leaders are seeking from new graduates.

\subsection{Operations Management vs. Supply Chain Management Curricula}

By the end of the 1990s, the newest versions of operations management curricula included process analysis, production systems, operations strategy, and supply chain management (Chase \& Zhang, 1998). SCM's addition into the OM course content in the 1990s was a continuation of the changing and innovative evolution of the Operations Management field (Chase \& Zhang, 1998). In the 1970s, it was Material Requirement Planning (MRP); in the 1980s it was Total Quality Management (TQM) and Just in Time (JIT), which were added to the growing curriculum of OM (Chase \& Zhang, 1998). In their paper, Chase and Zhang (1998) consider SCM as another tool in the larger OM toolbox, similar to forecasting techniques, Economic Order Quantity (EOQ), MRP, scheduling theory, and production planning. Kannan and Tan (2005) compared JIT, TQM and SCM, and claimed they were simply "alternate approaches to improving the effectiveness and efficiency of an organization's operations function" (p.153) and a part of the operations strategy of a business. Such views of SCM as a new tool in the larger OM literature are still widely shared by many in academia even though this would be considered as a very narrow definition compared to what the CSCMP described. Indeed, as late as 2006, Harland et al. claimed that SCM "is not yet a discipline, that there has been insufficient discipline and theory development" (Harland, et al., 2006, p. 730).

When Welborn and Singer conducted their research, published in 2013 on the contemporary OM textbook content, supply chain management was included in every OM textbook they analyzed. As textbook editions and curriculum changes extensively influence each other, $100 \%$ inclusion of SCM content in current OM textbooks shows that SCM and OM are related curriculums. According to some, contemporary SCM is nothing more than a simple relabeling of certain OM concepts under a SCM banner, with perhaps a broader systematic view (Johnson \& Pyke, 2000). Surprisingly, Welborn and Singer (2013) noticed that only $36 \%$ of the jobs listed as OM positions included SCM as a requirement even though SCM is still most demanded skill for an $\mathrm{OM}$ job. They considered this as a 
disparity between reality in the job market and the current curriculum of the business schools. It is likely that SCM and $\mathrm{OM}$ are two related and yet different fields from the business perspective. SCM and OM are related fields and this is why $36 \%$ of the jobs in OM demand a SCM knowledge and they are separate fields which explains why the remaining $64 \%$ of OM job listed do not require SCM knowledge.

\subsection{Operations Management Related Subject Areas}

Production management, management science, and operations research are usually subjects taught under the broad OM umbrella. Production management can be defined as managing the activities associated with transformation of commodities, materials, and services into the higher utility products (Mentzer, Stank, \& Esper, 2008). OM is a more general term that incorporates operations research and management science tools in the decision making in business problems (Mentzer, Stank, \& Esper, 2008). In a typical undergraduate OM course, many topics from production management, operations research, management science, and project management are included in order to use the available allocated time in the best way possible. In a recent study of management science in business schools, Palocsay and Markham (2014) draw a pessimistic view of the field and state management science has "limited visibility" at this point. In other words, management science is becoming a sub-subject of the general OM field. In this study, production management, management science, operations research, and project management are considered under the general umbrella of OM.

\subsection{Supply Chain Management and Logistics}

In order to meet the increasing demand for professionals in various companies there are far more logistics and SCM courses now than what was found in the 1990s (Tong, 2011). Another study counted 118 logistics courses in 77 schools from six countries (Lutz \& Birou, 2013). In Tong's study, logistics and SCM were considered as part of the same area. Also the Council of Supply Chain Management Professionals (CSCMP) (2013) SCM definition incorporates Logistics as a subsection of the larger SCM field. In contrast, another group of researchers state that "Supply chain risk management is one of the fastest growing areas in logistics research" which would equate SCM as a subarea of logistics management (Wang et al., 2014). However, there is little disagreement that logistics and SCM are very closely related areas with highly overlapping coverage. Indeed, some of the traditional logistics problems such as distribution planning are simply labeled as SCM problems (Das \& Lashkari, 2015; Thormann, 2015).

Considering the limited resources of business schools in providing so many electives, combining SCM and logistics together seems a reasonable compromise in business education at this point. Many ranking organizations of business schools including U.S News categorize logistics and SCM under the same category (Ellram \& Cooper, 2014). Hence, in this study, we also group logistics with SCM. For schools large enough in terms of student enrolment and program offerings, there are separate logistics and supply chain classes as electives requiring similar prerequisites. However, none of the schools offers both a supply chain class and a logistics class in their business core curriculum at the same time. These subjects, logistics and SCM, are always combined if they are required in the core business curriculum. For instance, at PennState University, students first take a general SCM class then followed by specific courses in Transportation Systems, and Logistics System Analysis and Design. It appears that more universities are moving towards considering logistics as a specialized area of Supply Chain Management. We did not focus on looking at all the elective courses in these two areas since our focus is to determine the place of SCM in the core business area.

\section{METHODOLOGY}

\subsection{Data Collection}

This research was divided into two phases in order to develop a descriptive analysis of OM and SCM courses in the core business curriculum.

1. Examine the business core curriculum at AACSB (Association to Advance Collegiate Schools of Business) accredited school to see if they offer SCM in their business core as

a. A combined SCM and OM course

b. A single course of SCM alone without also offering OM

c. Two separate courses in SCM and OM.

2. Conduct a survey of the schools that have made significant changes to incorporate more SCM in their core business program to further analyze their reasons for doing so and whether or not these changes produced positive results.

In the first phase, we gathered the list of accredited U.S. business schools through the AACSB website. Even though AACSB includes U.S. and non-U.S. higher learning institutes, the number of non-U.S. institutes is much less than the number of U.S. schools accredited. Additionally, the approval process of a new curriculum from one country to another one can be different and may reflect the demand of a local job market. Although there are many higher education institutions in the U.S. that either do not seek AACSB accreditation or do not qualify, we exclude non-AACSB schools because it would be more difficult to assess the quality of their curriculum development. AACSB accreditation has become a "de facto quality standard" for business schools (Gundersen, et al., 2011). In October 2014 there were 716 accredited schools listed on the AACBC website; 510 of these 716 schools (71\%) are in the U.S while the remaining 206 schools are located in 48 other countries. Appendix A gives a complete breakdown of AACSB accredited business schools by country. Among the international countries, only the UK and France have more than 20 schools with AACSB accreditation (see Figure 1). 


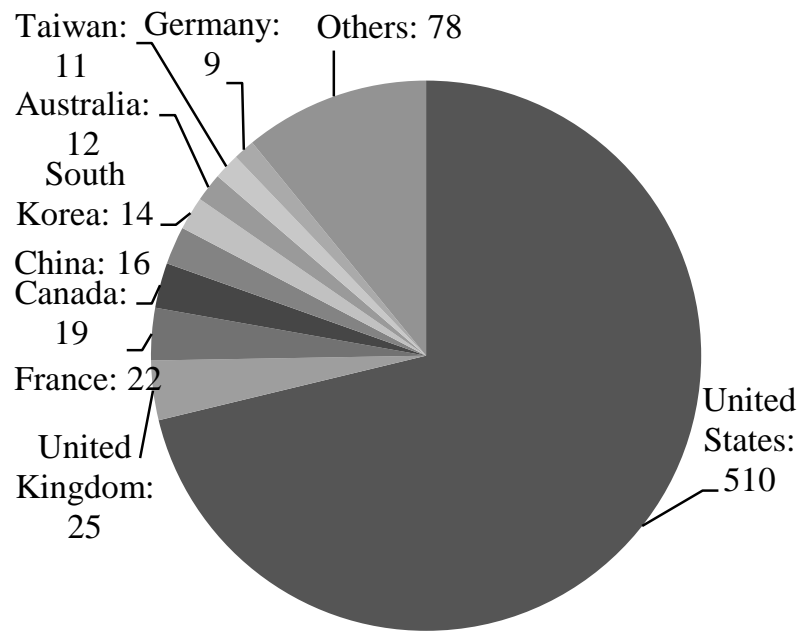

Figure 1: The number of AACSB business schools by country (Source: AACSB International, 2015)

Some of the 510 AACSB accredited US business schools do not offer a general management undergraduate program, and instead offer degrees such as Accounting and Marketing. Other business schools do not clearly state their core classes in the university catalog. After an exhaustive investigation of university website, we found 447 schools in the U.S. that have a clear list of core course requirements. This represents $87.6 \%$ of the AACSB accredited schools in the U.S. According to Farmer \& Abdelsamad (2014), there are 1,653 business schools in the U.S., including both AACSB accredited and nonaccredited institutions. Our study included 27\% (or 447) of the U.S. business schools.

We created a profile for each listed business school, including whether the school offers OM, SCM, or combined course in their core business program. "Combined" refers to classes where a combined operations and supply chain management related subject is being taught. This is different from a typical operations management course where SCM is a small portion of the course subject matter. For our study, combined courses must include supply chain management in the course title. Some of the combined course may represent nothing deeper than simply a small adjustment of content. However, such changes show that the faculty at the school felt it was important to add supply chain to the title even if there was not a comprehensive change in term of the course content. In addition, some schools offer an OM or SCM related courses, even though their courses' titles may not include the keywords of "operations management" or "supply chain management". Courses, which have the nature of OM or SCM, are included in our analysis.

Examples for operations management related courses include management science, business process and systems, and production management. An example of the supply chain management related course is logistics. The distinction is made whenever a separate course for operations management or supply chain management in the business core is offered. For instance, if a school offers both operations management and management science, their content is likely to be more divergent compared to a business school that has only a course of management science but no course in operations management. In the second case, there is likely to be a significant overlap between the content of the management science course and typical operations management content. For the majority of these cases, a syllabus or a catalog description of the course was examined to further clarify the content. There are also many instances, when business schools added terms like "international", "service", "production", or "technology" to show their particular interest. They are also included as a part of OM or SCM courses.

The list of other names for OM courses and other names for SCM courses is provided in Appendix B and Appendix C respectively. For example, other $\mathrm{OM}$ names include introduction to management science, management of business process, managerial planning and decision-making, process and system management, and quantitative methods for management. Logistics is the most frequently found course title, which we include as a part of SCM. Appendix D contains the list of course names for combined OM and SCM courses.

In the second stage, we contacted the business schools from the first stage that had changes in their core business curriculum related to SCM. This stage is the continuation of the earlier stage with an aim to further understand why these schools made these changes and to determine whether these changes led to positive outcomes. Survey data collection started with identifying key personnel in each school and contacting them for the survey. Key personnel included chairs of operations management or a related area, or a chair/dean of the business school or an administrative/teaching person to whom we were directed by the school. We contacted 43 business schools during the spring 2015, and had 15 completed surveys. The response rate was $34.9 \%$. Survey data was collected anonymously and no financial incentive was provided. We have no reason to believe the non-response rate created any bias. Survey results show similar demographics with the survey population.

\subsection{Data Analysis}

We used traditional survey methods to collect the data for the second stage of our study. The survey consisted mainly of five point Likert scaled questions, where 1 shows strong disagreement with the question being asked, 5 shows strong agreement, 3 shows neither disagreement nor agreement, 2 shows disagreement and 4 shows agreement. We calculated simple averages for the numerical survey questions. We later put data into cross sectional tabular format in order to further analyze the results. There were a few open-ended questions designed to gain further understanding of the issues relevant to the study. Those answers were analyzed and summarized collectively without using numerical scales.

\subsection{Demographic Data}

In terms of the schools surveyed and the responses received, we have business schools that vary in size: $42 \%$ of the 
schools have between 1000-2000 students; $34 \%$ of the schools have more than 2000 students; whereas $25 \%$ of the remaining schools have less than 1000 students. This is fairly representative of the size of typical US business schools. 17\% of the schools have Ph.D programs in Business, $67 \%$ of schools surveyed have specialized MA/MS degree in business related areas, $83 \%$ of the schools have MBA, and all of the schools have undergraduate business programs. Therefore, we have very top level schools with Ph.D. offerings as well as schools with only undergraduate programs in business. $42 \%$ of the schools surveyed and responded have more than 60 faculty, the remaining business schools have less than 60 faculty.

\section{RESULTS}

Table 1 summarizes the findings from 447 AACSB accredited business schools in the United States in terms of OM and SCM offerings in their business core curriculum.

Table 1 Percentage of Universities that Offer OM, SCM, or combined OM \& SCM Related Course in Their Core Curriculum.

\begin{tabular}{|l|l|l|l|l|l|}
\hline Groups & $\begin{array}{l}\text { OM Related } \\
\text { Course in the Core }\end{array}$ & $\begin{array}{l}\text { SCM } \\
\text { Related Course in the Core }\end{array}$ & $\begin{array}{l}\text { Combined OM \& SCM Related } \\
\text { Course in the Core }\end{array}$ & Frequencies & Percentage \\
\hline 1 & YES & NO & NO & 338 & $75.62 \%$ \\
\hline 2 & NO & NO & NO & 66 & $14.77 \%$ \\
\hline 3 & NO & NO & YES & 27 & $6.04 \%$ \\
\hline 4 & NO & YES & NO & 13 & $2.91 \%$ \\
\hline 5 & YES & YES & 3 & $0.67 \%$ \\
\hline Total: & & & 447 & $100.00 \%$ \\
\hline
\end{tabular}

Universities in Group 1 comprise the majority of the universities. These universities offer a single OM course in their core curriculum, and account for $75.62 \%$ (338 universities). SCM is not included in the course title even though these OM courses are very likely to cover SCM in a few chapters as a part of their curriculum. We classify this large group of schools as the "traditional" group.

Group 2 is comprised of universities that do not require or offer operations management, supply chain management, or the combined subject in their core curriculum. This group represents $14.77 \%$ of the schools (66 universities). When we reviewed this list, these schools often fall into two major subgroups. One of them is populated by private, liberal arts, smaller (enrollment-wise) institutes that may not have enough resources to offer OM or prefer other subjects in their core business program instead of an OM course. For instance, the Department of Business, Management, and Accounting at the University of Maryland Eastern Shore, a public school, offered one undergraduate program and had 285 undergraduate and graduate students; McColl School of Business at the Queens University of Charlotte, a private school, offered one undergraduate program and had 242 undergraduate and graduate students (AACSB International, 2014). The second subgroup in Group 2 is sizeable schools that want to give more flexibility to their students in choosing their courses. Bahouth et al. (2014) noted that universities might omit one or two core classes to give flexibility and opportunity for their students to take slightly different set of courses. Some of the schools, which prefer more flexibility in their business core, require their students to take one quantitative subject from a list that also includes OM. For instance, College of Business and Public Administration at the Eastern Washington University, a public school, provides 9 undergraduate programs to 970 business major students. In the upper-division courses, students can choose three courses from six available courses such as operations management, principle of marketing, and macroeconomics.

Group 3 schools offer a single combined course with both $\mathrm{OM}$ and SCM course in their course title. This group is $6.04 \%$ (27 universities) of all schools we researched. The title change in their course may reflect either a significant shift of SCM content or simply an adjustment to the new reality in the job market, which favors students with a SCM background. The next two groups of schools represent the most interesting cases. In Group 4, schools offer only a SCM course in the core and this course does not mention OM in their title, and Group 5 schools offer a SCM related course and an OM related course as two separate courses in their business core. Group 4 is $2.91 \%$ (13 schools) and Group 5 is only 0.67\% (3 schools). Universities in Group 4 or Group 5 demonstrate a larger commitment to including supply chain concepts in the business core than do Group 3 schools. In Group 4 schools, the SCM course may include OM as a part of the curriculum, as there is a growing claim in academia and the business community that $\mathrm{OM}$ is a part of SCM and not vice versa. Group 5 schools offer $\mathrm{OM}$ and SCM as two separate courses in their business core, which is considered to be the best fit for their programs.

In Table 2, we look at the universities with the top 32 undergraduate programs in business according to the U.S. News Best Business Schools report. Comparing to Table 1 and Table 2, it is clear that a smaller percentage of top business schools are in Group 1 (75.62\% vs 68.75\%), schools that require a single $\mathrm{OM}$ related course in their business core. However, the total percentage of schools in Groups 3, 4, and 5 is much higher for the top schools (9.62\% vs $15.63 \%$ ). Group 4 schools that have replaced OM with SCM have a remarkably 
higher percentage $(2.91 \%$ vs $9.38 \%)$ for the top schools as do the Group 5 schools $(0.67 \%$ vs $3.13 \%)$ that offer both an OM and a SCM course. Group 2 schools that have neither OM nor $\mathrm{SCM}$ are at a similar percentage $(15.63 \%$ vs $14.77 \%)$. We can conclude that top schools show a stronger trend to switch to a SCM emphasis compared to the rest of the schools. This may show that the top schools are actually leading the changes, but that the change to SCM is still in its infancy.

Table 2 Percentage of Top 32 universities that offer OM, SCM, or a combined OM \&SCM related course in their core curriculum.

\begin{tabular}{|l|l|l|l|l|l|}
\hline Groups & $\begin{array}{l}\text { OM Related } \\
\text { Course in the Core }\end{array}$ & $\begin{array}{l}\text { SCM } \\
\text { Related Course in the Core }\end{array}$ & $\begin{array}{l}\text { Combined OM \& SCM Related } \\
\text { Course in the Core }\end{array}$ & Frequencies & Percentage \\
\hline 1 & YES & NO & NO & 22 & $68.75 \%$ \\
\hline 2 & NO & NO & NO & 5 & $15.63 \%$ \\
\hline 3 & NO & YO & NO & 1 & $3.13 \%$ \\
\hline 4 & NO & YES & NO & 3 & $9.38 \%$ \\
\hline 5 & YES & YES & 1 & $3.13 \%$ \\
\hline Total: & & 32 & $100.00 \%$ \\
\hline
\end{tabular}

In the second stage, we sent surveys to the 43 schools in Group 3, 4, and 5, which have made changes related to integrating SCM into their business core curriculum. We have results from 15 schools who have responded our survey. Figure 2 shows the main motivations for the change. Survey respondents could choose as many of the multiple options as they felt applied.

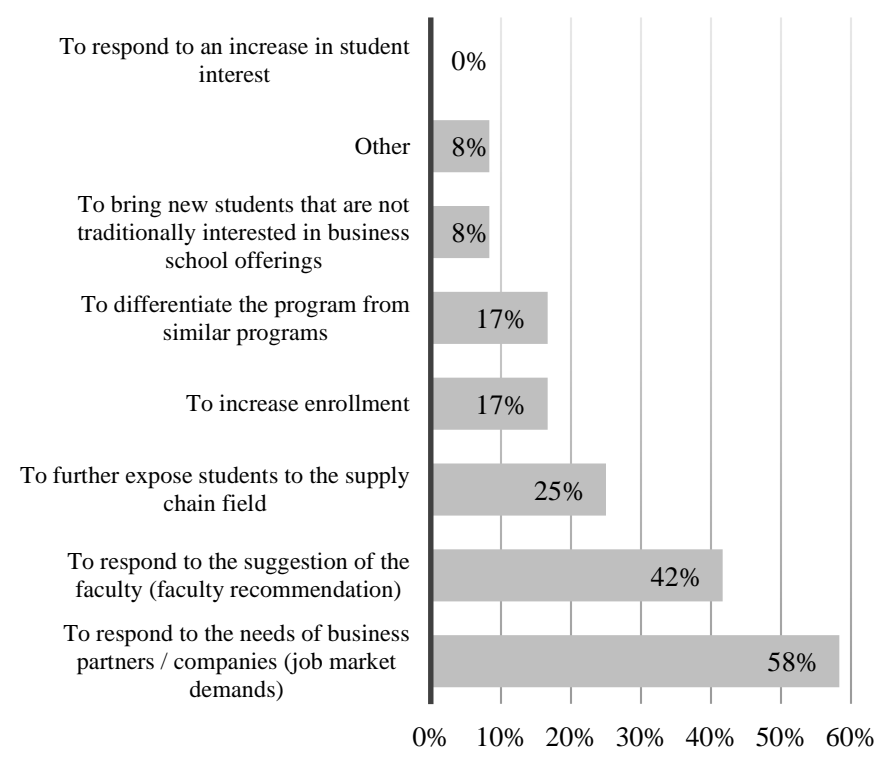

Figure 2 The main motivations for changes related to increasing the SCM content in the business core curriculum

It is interesting to see none of the respondents chose to respond to an increase in student interest. As SCM is a relatively new field, this is not surprising. It is difficult to imagine students who have graduated from a high school or who are in their freshmen or sophomore years who would know enough about the field to make requests to include more SCM in the business core at their schools. Faculty and the business partners are the main factors behind the changes with $42 \%$ and $58 \%$ of the schools reporting that these groups were main motivators for increasing the supply chain content of the business core. This shows a clear challenge of business schools related to SCM. Although there is a demand for SCM skills in the business world, business students are less informed about the field and its increasing job opportunities. Offering an introductory class in the business core would arguably give adequate information about the SCM field before students choose their final graduation degree within the business school.

In terms of understanding the reaction to the changes related to increasing the SCM content in business curriculum, we sought input from three major stakeholders. These are students, business faculty and OM Faculty. Figure 3 lists the reactions of these groups according to the survey respondents.
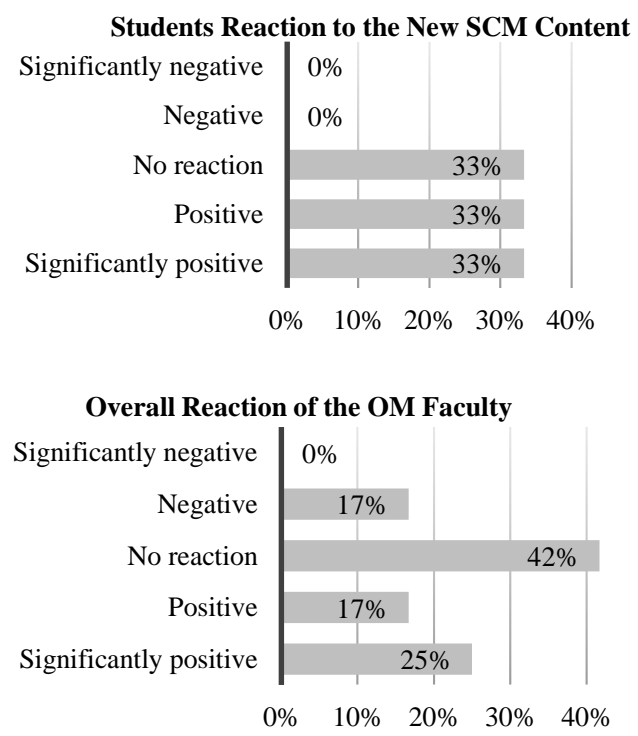

Overall Reaction of the Business Faculty

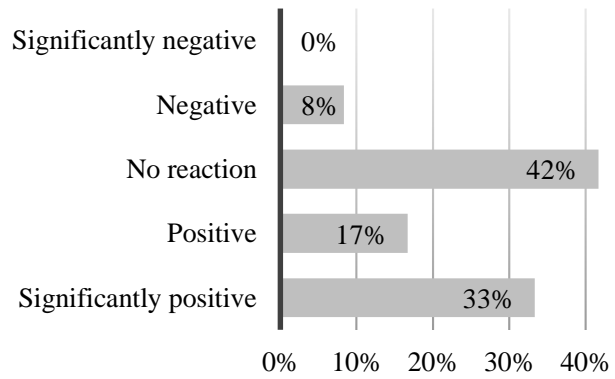

Figure 3 Reaction from students and faculty 
Students in general show either no reaction or positive reaction according to survey respondents. It would appear that the business students were in general fine with the decisions that were made by their business school. The business faculty (non-OM) show less strong positive results, but the negative reaction is also limited to only $8 \%$ of the respondents who reported a negative reaction from the rest of the business faculty. Considering only 3 out of 43 schools had both SCM and $\mathrm{OM}$ in the business core, it is likely that most business faculty felt the changes were nothing more than updating of course content to be more relevant to the modern job market. There are 13 schools that replaced OM with SCM. For the business faculty in other disciplines this would not be seen as major changes from their perspective. Interestingly, OM faculty are the most negative among these three groups. OM and SCM are closely related fields so a large portion of the faculty would be trained to adequately teach both subjects. However, some OM faculty may feel that their jobs are threatened with the new changes or they may feel their favored subject of $\mathrm{OM}$ is being given a lower profile by becoming a part of the relatively new field of SCM. It is clear that OM faculty can be one of the obstacles in implementing more SCM into business curriculum. We now investigate how the business world reacted to these changes.

In terms of benefits to students in finding internships and jobs, SCM showed significant positive results. Figures $4 \mathrm{a}$ and $4 \mathrm{~b}$ summarize the results.

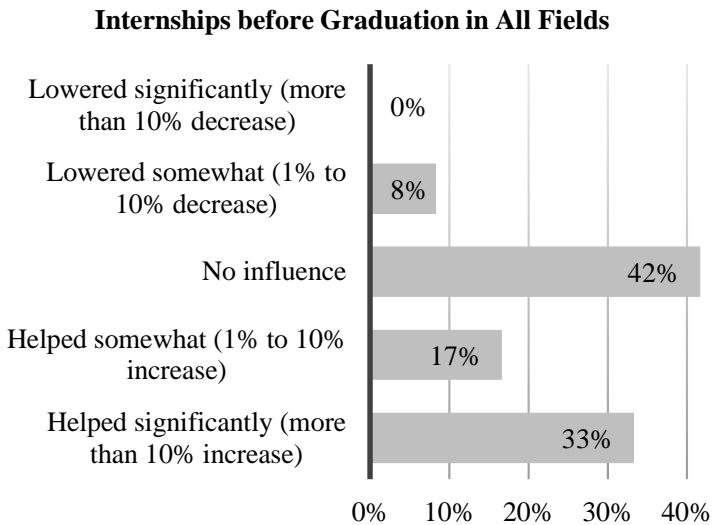

Employment after Graduation in All Fields

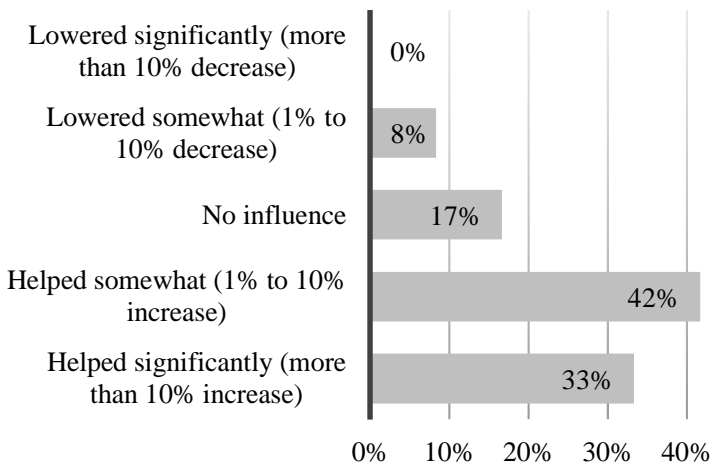

Figure 4a The effect of changes related to SCM in the business core in terms of internships and employment (all fields)
Figure 4a shows that increased SCM content was believed to have helped students to find internships before graduation or land jobs afterwards. Although we did not directly collect data on internships or jobs it is important to remember that most of the individuals polled do have access to the internship and employment data of their students. It is also interesting to note that employment after graduation $(75 \%$ in the helped somewhat or helped significantly categories) was believed to be more positively affected than were internship before graduation $(50 \%$ in the helped somewhat or helped significantly categories). Given that companies are trying to recruit more "well rounded" candidates, knowledge in diverse areas such as SCM may help candidates whose primary jobs are in one of the traditional business area such as marketing. Internships are often more focused on using short-term skills in a primary area. Thus, this may explain the difference between the employment and internship data. Figure $4 \mathrm{~b}$ shows that $84 \%$ of the respondents felt that increasing the SCM content in the business core helped students land internships in SCM before graduation or jobs in SCM after graduation.

Internships in the SCM Area before Graduation

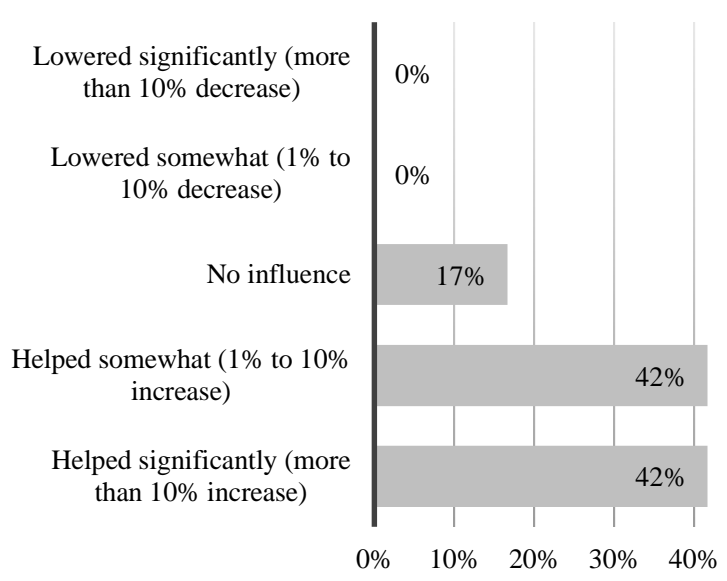

Employment in the SCM Area after Graduation

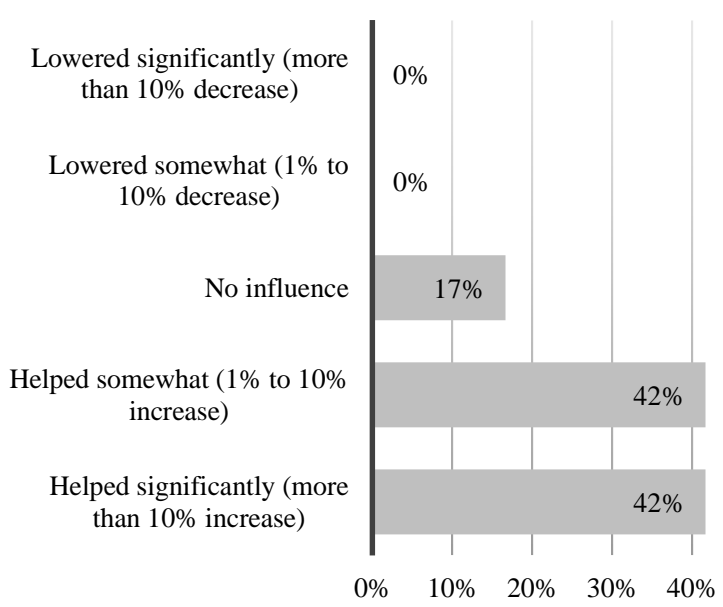

Figure 4b The effect of changes related to SCM in the business core in terms of internships and employment (SCM field) 
It is also noteworthy that helped somewhat and helped significantly are equally distributed with $42 \%$ for both internship and employment data in Figure $\mathbf{4 b}$. So the question is, if the changes are helpful, why do they not help significantly instead of just being somewhat helpful? Figure $\mathbf{5}$ may give some explanation.

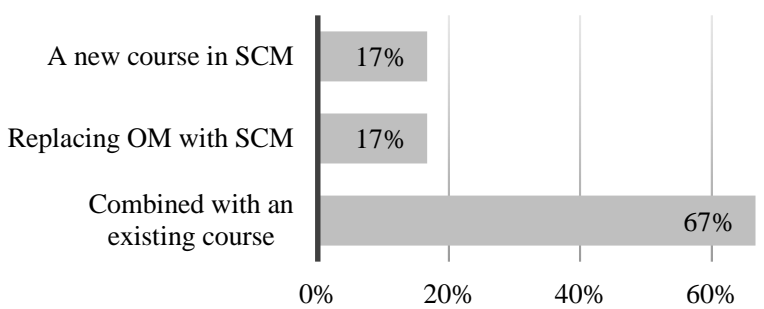

Figure 5 The format of having SCM content in the business core

Figure 5 shows that $2 / 3$ of the schools, which responded to our survey simply combined SCM with an existing OM course. Only $17 \%$ replaced $\mathrm{OM}$ and $17 \%$ introduced a new course in SCM. With so little change in integrating SCM into the business curriculum, only so much benefit can be gained in terms of internships and employment in the SCM area.

Figure 6 shows increasing the SCM content in the business core did not increase the budget in $67 \%$ of the schools. In addition, in only $8 \%$ of the school the change significantly increased the budget (more than a $10 \%$ increase). This is good news for the schools considering similar changes.

\section{Cost of Implementation}

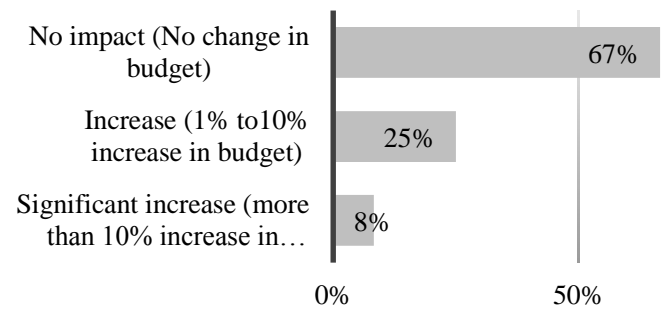

Funding for the Implementation

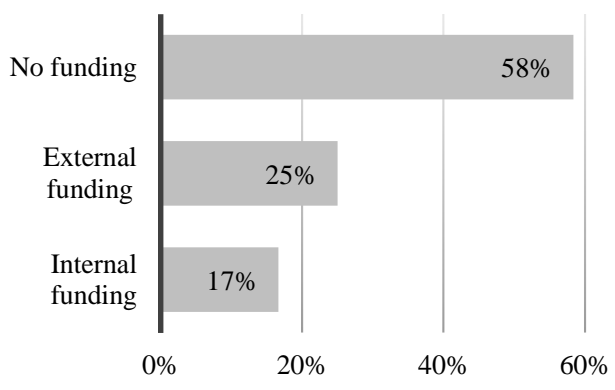

Figure 6 Cost and Funding
We also collected demographic data from the schools surveyed. Figure 7 shows the schools surveyed included both smaller schools and much larger schools with many faculty members. Seventeen percent of the schools offer a $\mathrm{PhD}$ degree in business, while $17 \%$ only offer undergraduate degrees in business. We believe that SCM related changes can be implemented for practically all schools as long as there is a faculty support for these changes.

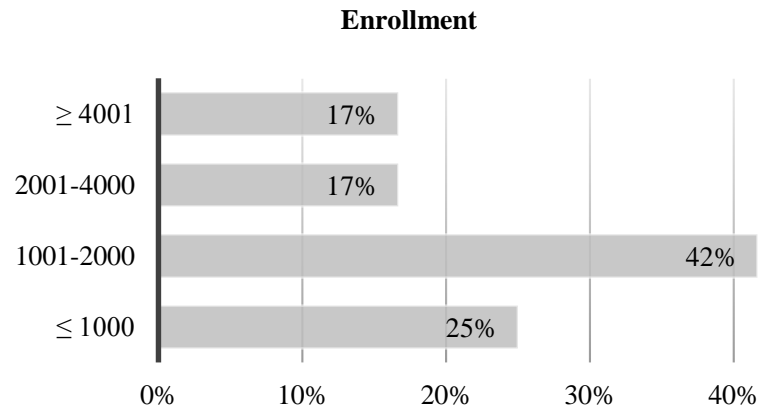

Number of Business Degrees/Majors Offered

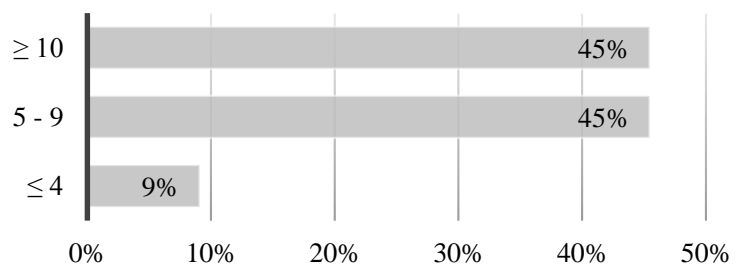

Business Programs Offered

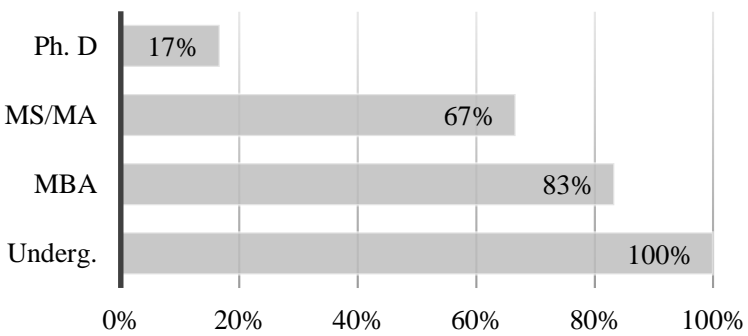

Total Number of faculty

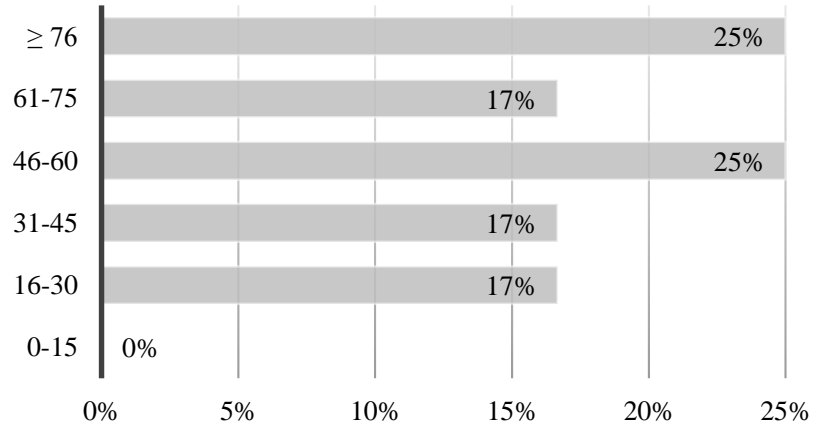

Figure 7 Demographics of the schools surveyed. 


\section{CONCLUSION}

In this paper, we investigated 447 business schools with AACSB accreditation in the U.S., representing $87.6 \%$ of the 510 AACSB accredited business schools in the U.S. This study developed a descriptive analysis of OM and SCM courses in the core business curriculum: $75.62 \%$ of business schools offer OM only in their core curriculum; $14.77 \%$ of business schools do not offer operations management, supply chain management, or a combined subject in their core curriculum; $6.04 \%$ of business schools have a core course that combines $\mathrm{OM}$ and SCM, while $2.91 \%$ of business schools offer only $\mathrm{SCM}$ in their core curriculum and less than $1 \%$ of business schools offer both OM and SCM in their core curriculum.

We found that changing the title of the OM course to include SCM could be beneficial to most business schools as it increases the focus of the SCM content in the combined course. Students benefit in finding internships and jobs in their both primary area and in SCM area. Importantly such changes will not increase budgets significantly for the great majority of business schools. Their current faculty may be sufficient to implement these changes. However, small changes may not be enough for the SCM field in which there is growing need of highly educated students. For the future, business schools must consider including SCM as a separate required class, or offering a separate degree in SCM. This would also help to decrease the pressure for the OM faculty to cover so many subjects in a single OM class and help to decrease the potential impact for students who attempt to find jobs in traditional OM areas.

This study included only U.S. business schools with the AACSB accreditation, thus, we have screened out other business schools that offer OM, SCM and the combined subject. In total, there are about 1,653 business schools in the U.S., and 14,018 business schools in other countries (Farmer \& Abdelsamad, 2014, p. 5). This study included approximately $27 \%$ (447) of business schools in the U.S. but it excluded all business schools outside the U.S. There is definitely a need for a future study to investigate international business schools to compare the similarities and differences to their U.S. counterparts in integrating supply chain management into the business curriculum.

\section{REFERENCES}

AACSB International. (2014). Accredited Institutions: Full Global List. Retrieved from AACSB International: http://www.aacsb.edu/en/accreditation/accreditedmembers/global-listing/

Alfalla-Luque, R., \& Medina-Lopez, C. (2009). Supply chain management: Unheard of in the 1970s, core to today's company. Business History, 51(2), pp. 202-221.

Bahouth, S., Hartmann, D., \& Willis, G. (2014). Supply chain management: How the curricula of the top ten undergraduate universities meet the practitioners' knowledge set. American Journal of Business Education (AJBE), 7(4), pp. 285-289.

Bowersox, J. D., Closs, D. J., Cooper, M. B., \& Bowersox, J. C. (2013). Supply chain logistics management (4th ed.). New York: McGraw-Hill.
Chase, R. B., \& Zhang, A. (1998). Operations management: Internationalization and interdisciplinary integration. International Journal of Operations \& Production Management, 18(7), pp. 663-667. doi:10.1108/01443579810217648

Council of Supply Chain Management Professionals. (2013, August). Supply chain management terms and glossary. Retrieved from Council of Supply Chain Management Professionals: http://cscmp.org/sites/default/files/user_uploads/resources/dow nloads/glossary-2013.pdf

Das, K., \& Lashkari, R. S. (2015). A Supply Chain Product Delivery and Distribution Planning Model. Operations and Supply Chain Management: An International Journal, 8(1), pp. 22-27.

Ellram, L. M., \& Cooper, M. C. (2014). Supply chain management: It's all about the journey, not the destination. Journal of Supply Chain Management, 50(1), pp. 8-20. doi:10.1111/jscm.12043

Farmer, B. M., \& Abdelsamad, M. H. (2014). Improving the odds of maintaining AACSB accreditation. SAM Advanced Management Journal (07497075), 79(1), pp. 4-11.

Grandzol, J. R., \& Grandzol, C. J. (2011). An experiential approach to benchmarking curriculum. Decision Sciences Journal of Innovative Education, 9(3), pp. 401-409.

Gundersen, D. E., Jennings, S. E., Dunn, D. L., Fisher, W. W., Kouliavtsev, M., \& Rogers, V. C. (2011). A pillar for successful business school accreditation: Conducting the curriculum review process - a systematic approach. American Journal of Business Education, 4(5), pp. 39-48.

Harland, C. M., Lamming, R. C., Walker, H., Phillips, W. E., Caldwell, N. D., Johnsen, T. E., . . Zheng, J. (2006). Supply management: Is it a discipline? International Journal of Operations \& Production Management, 26(7), pp. 730 - 753.

Johnson, M. E., \& Pyke, D. F. (2000). A framework for teaching supply chain management. Production and Operations Management, 9(1), pp. 2-18.

Jones, M. A., Cope, R., \& Budden, M. C. (2009). The multidisciplinary nature of supply chain management: Where does it fit in business education? American Journal of Business Education, 2(1), pp. 17-24.

Kannan, V. R., \& Tan, K. C. (2005). Just in Time, Total Quality Management, and Supply Chain Management: Understanding their Linkages and Impact on Business Performance. Omega, 33(2), pp. 153-162. doi:10.1016/j.omega.2004.03.012

Korn, M. (2013, June 5). The hot new M.B.A.: Supply-chain management. Retrieved October 1, 2014, from The Wall Street Journal: http://online.wsj.com/news/articles/SB10001424127887324423 904578523591792789054

Lutz, H., \& Birou, L. (2013). Logistics education: A look at the current state of the art and science. Supply Chain Management: An International Journal, 18(4), pp. 455 - 467. doi:10.1108/scm08-2012-0269

Mentzer, J. T., Stank, T. P., \& Esper, T. L. (2008). Supply chain management and its relationship to logistics, marketing, production, and operations management. Journal of Business Logistics, 29(1), pp. 31-46.

Neureuther, B. D., \& O'Neill, K. (2011). Sustainable supply chain management programs in the 21 st century. American Journal of Business Education, 4(2), pp. 11-18.

Palocsay, S. W., \& Markham, I. S. (2014). Management science in US AACSB international-accredited core undergraduate business school curricula. Journal of Education for Business, 89(2), pp. 110-117.

Thormann, M. (2015). Integration of Real-Time Demand Information and Spare Parts Distribution Planning for the Optimization of Spare Parts Supply in After-Sales Service Networks. Operations 
and Supply Chain Management: An International Journal, 8(1), pp. 1-10.

Tong, J. (2011). Managing logistics higher education using logical: Framework analysis. International Journal of Innovation, Management and Technology, 2(4), pp. 309-314.

Wang, M., Jie, F., \& Abareshi, A. (2014). The measurement model of supply chain uncertainty and risk in the Australian courier industry. Operations and Supply Chain Management: An International Journal, 7(3), pp. 89-96.

Welborn, C. A., \& Singer, M. G. (2013). Operations management: Is there a disconnect between college textbook content and employer needs? Journal of Education for Business, 88(1), pp. 1-7. doi:10.1080/08832323.2011.629237

Dr. Gurkan I. Akalin is an Assistant Professor in the School of Business at the Eastern Illinois University. He earned his Ph.D. in Management Science from the University of Texas at Arlington. He received a Master's of Science degree in Industrial Engineering from the Georgia Institute of Technology, and received his undergraduate degree in Industrial and Systems Engineering from the University of Southern California. His research interests include risk management, supply chain management, curriculum development, operations management, and supply chain-finance interface. E-mail: giakalin@eiu.edu (corresponding author).

Zhentu Huang is an MBA graduate from the School of Business at the Eastern Illinois University. He holds additionally a Bachelor's of Science degree from the University of Toledo. E-mail: Zhuang@eiu.edu.

Dr. John R. Willems is a Professor and Chair of the School of Business at Eastern Illinois University. He earned his Ph.D. from Indiana University. His research interests include quantitative modeling, enterprise resource planning and supply chain management. E-mail: jrwillems@eiu.edu. 


\section{APPENDICES}

\section{APPENDIX A: NUMBER OF AACSB BUSINESS SCHOOLS (N=715) BY COUNTRY (OCTOBER}

2014)

\begin{tabular}{|c|c|c|}
\hline United States $(510,71.4 \%)$ & Turkey $(3,0.5 \%)$ & Egypt $(1,0.2 \%)$ \\
\hline United Kingdom (25, 3.5\%) & United Arab Emirates $(4,0.6 \%)$ & Indonesia $(1,0.2 \%)$ \\
\hline France $(22,3.1 \%)$ & Belgium $(2,0.3 \%)$ & Ireland $(1,0.2 \%)$ \\
\hline Canada $(19,2.7 \%)$ & Brazil $(2,0.3 \%)$ & Israel $(1,0.2 \%)$ \\
\hline China $(16,2.3 \%)$ & Chile $(2,0.3 \%)$ & Italy $(1,0.2 \%)$ \\
\hline South Korea $(14,2 \%)$ & Colombia $(2,0.3 \%)$ & Kuwait $(1,0.2 \%)$ \\
\hline Australia $(12,1.7 \%)$ & Denmark $(2,0.3 \%)$ & Lebanon $(1,0.2 \%)$ \\
\hline Chinese Taipei $(11,1.6 \%)$ & Finland $(2,0.3 \%)$ & Malaysia $(1,0.2 \%)$ \\
\hline Germany $(9,1.3 \%)$ & Japan $(2,0.3 \%)$ & Norway $(1,0.2 \%)$ \\
\hline New Zealand $(7,1 \%)$ & Portugal $(2,0.3 \%)$ & Philippines $(1,0.2 \%)$ \\
\hline Mexico $(4,0.6 \%)$ & South Africa $(2,0.3 \%)$ & Poland $(1,0.2 \%)$ \\
\hline Netherlands $(4,0.6 \%)$ & Thailand $(2,0.3 \%)$ & Qatar $(1,0.2 \%)$ \\
\hline Spain $(4,0.6 \%)$ & Argentina $(1,0.2 \%)$ & Saudi Arabia $(1,0.2 \%)$ \\
\hline India $(3,0.5 \%)$ & Canada $(1,0.2 \%)$ & Slovenia $(1,0.2 \%)$ \\
\hline Peru $(3,0.5 \%)$ & Costa Rica $(1,0.2 \%)$ & Venezuela $(1,0.2 \%)$ \\
\hline Singapore $(3,0.5 \%)$ & Croatia $(1,0.2 \%)$ & \\
\hline Switzerland $(3,0.5 \%)$ & Ecuador $(1,0.2 \%)$ & \\
\hline
\end{tabular}

Appendix A shows the number of AACSB accredited business schools broken down by country. Most of the AACSB accredited business schools are located in the United States, which accounts for 510 or $71.4 \%$ of all accredited schools. The second largest number of AACSB accredited business schools is in the United Kingdom, which accounts for 25 or $3.5 \%$ of all accredited business schools. $89 \%$ of the AACSB accredited business schools are located in the countries of United State, UK, France, Canada, China, South Korea, Australia, Chinese Taipei, Germany (see Figure 1).

\section{APPENDIX B: OM LIST OF COURSE NAMES}

Analyzing Business Operations

Business Operation

Business Processes and Systems

Global Operations Management

Integrated Functional Systems: Operations

Introduction to Management Science

Introduction to Production and Operations Management

Introduction to Service and Operations Management

Management of Business Process

Management of Operation and Technology

Management of Operations

Management of Productions/Operations

Management Science

Management Science and Operations Management

Management Science and Operations Technology

Management, Operations \& Technology Management

Managerial Planning and Decision Making

Managing Operation in a Competitive Environment 
Managing Production and Operations

Marketing-Operations Fundamentals

Operation and Quality Management

Operation and Service Management

Operations Management and Quantitative Methods

Operations Management in Business

Operations \& Project Management

Operations and Enterprise Management

Operations and Project Management

Operations and Quality Management

Operations and Technology Management

Operations Management and Strategy

Principles of Management and Operations

Principles of Operations Management

Principles of Operations Management and Introduction to Project Management

Process and Operations Management

Process and System Management

Production and Operations Management

Production Management

Production/Operations Management

Productions and Operations

Project \& Operations Management

Quality and Operations Management

Quantitative Methods for Management

Service Operations Management

Technology and Operations Management

\section{APPENDIX C: SCM LIST OF COURSE NAMES}

Business Logistics Management

Global Supply Operations

Integrated Supply Chain Management

Introduction to Supply Chain

Introduction to Supply Chain Management

Logistics

Principles of Supply Chain Management

\section{APPENDIX D: COMBINED LIST OF COURSE NAMES}

Business Processes and Supply Chain Management

Integrated Operations and Supply Chain Management

Introduction to Operations and Supply Chain Management

Introduction to Supply Chain and Operations

Operations and Logistics Management

Operations and Supply Chain Management

Operations Research and Supply Chain Management

Principles of Supply Chain \& Operations Management

Production, Supply Chain and Distribution Management

Supply Chain and Operations Management

Supply Chain Operations Management

Survey of Operations \& Supply Management 